\title{
Context and Strategy in Presidential Campaigns: Incumbency and the Political Climate
}

\author{
JAMES E. CAMPBELL and BRYAN J. DETTREY
}

\section{QUERY SHEET}

This page lists questions we have about your paper. The numbers displayed at left can be found in the text of the paper for reference. In addition, please review your paper as a whole for correctness.

Q1: Au: Please confirm edit in this sentence.

Q2: Au: Please clarify this sentence.

Q3: Au: Insert "who" here? It seems like there is a word missing.

Q4: Au: Need to specify both what?

Q5: Au: This URL does not work; please review.

Q6: Au: Please provide access date.

Q7: Au: Please provide additional details about this manuscript.

\section{TABLE OF CONTENTS LISTING}

The table of contents for the journal will list your paper exactly as it appears below:

Context and Strategy in Presidential Campaigns: Incumbency and the Political Climate James E. Campbell and Bryan J. Dettrey 


\title{
Context and Strategy in Presidential Campaigns: Incumbency and the Political Climate
}

\author{
JAMES E. CAMPBELL and BRYAN J. DETTREY \\ University at Buffalo, State University of New York, Buffalo, New York, USA
}

\begin{abstract}
We propose and examine a theory of how the context of the political climate and incumbency interact to affect candidate strategies and their impact on candidate evaluations and the vote in presidential elections. From this theory, we generate four hypotheses. Two concern the difference between elections in which the incumbent runs as opposed to open seat races with a successor in-party candidate. The other two bypotheses concern the difference in evaluations of incumbents and successor candidates in open seat elections. The results indicate that open seat elections are less reflective of the political climate than incumbent elections, that incumbents experience higher highs and lower lows than successor candidates, that evaluations of successor candidates tend to be more muted representations of evaluations of incumbents, and that the vote in open seat races depends more beavily on how voters judge the successor candidate rather than the incumbent leaving office. The contextual campaign made a substantial difference in 2008, allowing John McCain to distance bimself from the unpopular President Bush and to do significantly better in evaluations and at the polls than the incumbent would have.
\end{abstract}

KEYWORDS 2008 presidential election, campaign context, campaigns, incumbency, open seat elections, presidential elections

If there is a law of political campaigns, it must be that the consideration of the political context of the election is critically important in devising an optimal campaign strategy. Effective campaign strategies must be substantially

Address correspondence to James E. Campbell, Department of Political Science, University at Buffalo, SUNY, Buffalo, NY 14260, USA. E-mail: jcampbel@buffalo.edu 
shaped by the political context in which the election takes place. The political context in which a campaign takes place is what the voters have reacted to, or may yet react to, and supplies the raw material for the candidates' campaigns. The campaign's context is often referred to as "the fundamentals." In this article, we will examine how the two most important contexts of the presidential campaign-incumbency and the political climate-interact to direct the general thrusts of presidential campaigns and their roles in shaping the 2008 presidential race.

\section{INCUMBENCY AND THE POLITICAL CLIMATE IN CAMPAIGNS}

The role of incumbency in subpresidential elections has been fairly well understood for some time. In particular, there is an enormous literature on the effects of incumbency in congressional elections and how these have changed over the years (Abramowitz, 1991; Alford and Hibbing, 1981; Levitt and Wolfram, 1997). The differences between elections with running incumbents and open seat contexts have also been carefully examined (Gaddie and Bullock, 2000). The effects of presidential incumbency have not been as fully explored (Campbell, 2000, 2008a; Weisberg, 2002; Tenpas, 2003; Mayhew, 2008). The impact of presidential incumbency, however, is closely intertwined with retrospective evaluations of the incumbent's record, and this has been a carefully scrutinized subject (Lippman, 1925; Key, 1966; Fiorina, 1981). As Lippman put the simple retrospective voting rule about the in-party: "to support the Ins when things are going well; to support the Outs when they seem to be going badly, this, in spite of all that has been said about Tweedledum and Tweedledee, is the essence of popular government" $(1925,126)$.

What may be most important about incumbency as a context of a campaign is that a campaign without the incumbent running is less about the incumbent and the incumbent's record (Miller and Wattenberg, 1985; Campbell, 2001a; Nadeau and Lewis-Beck, 2001; Norpoth, 2002; Holbrook, 2008; Campbell, Dettrey, and Yin, 2009). In Lippman's terms, elections without the incumbent in the race are somewhat less about supporting the Ins or the Outs. When an incumbent is in the race, there ought to be greater certainty about the vote, since voters should generally have a more definite idea about whether things are going well and whether they approve or disapprove of the incumbent's record. Voters are likely to have less definite impressions about the candidates in an open seat race, even the relatively well-known national candidates of a presidential race. With conditions mattering somewhat less to voters in open seat races, there should be greater voter uncertainty about the two candidates.

The political climate in which a campaign takes place is essentially composed of the public's pre-campaign reactions to the content of the election: the issues, the records, and the candidates' strengths and weaknesses 
in leadership. The American Voter study referred to these as the short-term forces that affect elections (Campbell et al., 1960). How voters see and evaluate the substance of the election, applying their long-term partisan and ideological perspectives and predispositions to the content, leaves the electorate more or less favorably disposed to returning the in-party to office. The political climate encompasses all of the matters that voters think are relevant to their vote choice, weighted to the degree that voters consider these matters important and judged to be favorable or unfavorable to a party based on the voters' partisan and ideologically influenced judgments. The political climate amounts to whether the electorate as an audience is receptive to or hostile to a party and its candidate. This must affect the nature of the candidates' campaigns, whether the are in a defensive or offensive posture, and the nature of their campaign message. These are factors that affect all presidential campaigns, and the 2008 race between in-party Republican John McCain and out-party Democrat Barack Obama serves as a prime example of their effects.

\section{THE THEORY OF CONTEXTUAL CAMPAIGNS}

The interaction of incumbency and the political climate of the election should largely determine the basic strategy adopted by candidates in their campaigns. That context dictates the strategy is based on the simple idea, perhaps the first law of campaigns, that candidates should play to their strengths and their opponent's weaknesses. The theory of context dependent campaigns is summarized in Tables 1 and 2 .

Table 1 displays four ideal-type campaign contexts based on the interaction of incumbency and political climate and the basic campaign strategy that in-party candidates should adopt under each set of circumstances. The circumstances (across the rows) are (1) an incumbent running in an unfavorable political climate (an unpopular incumbent), (2) an incumbent running in a favorable political climate (a popular incumbent), (3) an open seat election

TABLE 1 Appropriate Campaign Strategies for In-Party Candidates in Different Incumbency and Political Climate Contexts

\begin{tabular}{|c|c|c|}
\hline \multirow{2}{*}{$\begin{array}{l}\text { In-party strategy } \\
\text { incumbency }\end{array}$} & \multicolumn{2}{|c|}{ Political climate } \\
\hline & Unpopular incumbent & Popular incumbent \\
\hline Incumbent in race & $\begin{array}{l}\text { Prospective campaign; incumbent } \\
\text { owns the record and emphasize } \\
\text { some successes }\end{array}$ & $\begin{array}{l}\text { Retrospective campaign; } \\
\text { incumbent owns the record } \\
\text { and emphasize role in } \\
\text { successes }\end{array}$ \\
\hline Open seat race & $\begin{array}{l}\text { Prospective campaign; distance } \\
\text { the successor in-party candidate } \\
\text { from the incumbent }\end{array}$ & $\begin{array}{l}\text { Retrospective campaign; link } \\
\text { the successor in-party } \\
\text { candidate to the incumbent }\end{array}$ \\
\hline
\end{tabular}


TABLE 2 Appropriate Campaign Strategies for Out-Party Candidates in Different Incumbency and Political Climate Contexts

\begin{tabular}{llc}
\hline \multirow{2}{*}{$\begin{array}{l}\text { Out-party strategy } \\
\text { incumbency }\end{array}$} & \multicolumn{2}{c}{ Political climate } \\
\cline { 2 - 3 } Incumbent in race & $\begin{array}{l}\text { Retrospective campaign; } \\
\text { incumbent owns the record } \\
\text { and emphasizes some } \\
\text { shortcomings }\end{array}$ & $\begin{array}{c}\text { Prospective campaign; incumbent } \\
\text { owns the record and } \\
\text { emphasizes some shortcomings }\end{array}$ \\
Rpen seat race & $\begin{array}{c}\text { Pespective campaign; link } \\
\text { the successor in-party } \\
\text { candidate to the incumbent }\end{array}$ & $\begin{array}{c}\text { Prospective campaign; distance } \\
\text { the successor in-party candidate } \\
\text { from the incumbent }\end{array}$ \\
\hline
\end{tabular}

with a successor candidate running in an unfavorable political climate (an unpopular incumbent), and (4) an open seat election with a successor candidate running in a favorable political climate (a popular incumbent).

Based on the premise that the campaign strategy that is most credible and most appealing to voters requires candidates to emphasize their strengths and de-emphasize their weaknesses, the strategies are easily deduced. In the first campaign context, with an unpopular incumbent in the race, lacking a popular record on which to run, the candidate must run a prospective forward-looking campaign emphasizing value agreements with voters. Unpopular incumbents cannot escape their record entirely, so they should also emphasize whatever successes they can credibly claim. An example of this situation would be Jimmy Carter's 1980 race. In the second campaign context, with a popular incumbent in the race, in-party candidates have an easy job of claiming credit for success and emphasizing their role in bringing it about. Examples of elections in this category would be Ronald Reagan's 1984 and Bill Clinton's 1996 reelection bids.

The third and fourth contexts involve open seat races. As in the first two contexts, the in-party candidates (successor candidates) run a retrospective campaign when conditions are good and a prospective campaign, de-emphasizing the record, when conditions are bad. Since these candidates are not the incumbents, they also can either more closely associate themselves with the outgoing administration in favorable political climates or attempt to put distance between themselves and the administration when that association is a liability. Examples of open seat elections with a popular incumbent would be George H. W. Bush's 1988 contest against Michael Dukakis and Al Gore's 2000 contest against George W. Bush. Examples of open seat elections with an unpopular incumbent would be Hubert Humphrey's 1968 contest against both Richard Nixon and George Wallace and John McCain's 2008 contest against Barack Obama.

There are two limitations to the effects of the in-party candidate's campaign. The first of these, of course, is the opposition's campaign. 
Table 2 presents the set of four contexts from Table 1, but now with the appropriate strategies from the standpoint of the out-party's candidate. In most respects, the appropriate strategy of the out-party candidate is the opposite of the in-party candidate. The in-party's strengths are weaknesses for the out-party candidate and they should be de-emphasized to minimize their effect on the vote. Conversely, the in-party's weaknesses are openings for the out-party candidate. The one exception to this reversal of strategies is that the out-party candidates cannot credibly dissociate the incumbents from their records. If the incumbent has a strong record, their opponents can point to possible failings in the record and attempt to move the public's attention to prospective matters, but that is about as far as they can really go. Moreover, the record and the retrospective evaluations of it may have a somewhat privileged status with voters, since they have their own information about it and, when it comes to a prospective campaign, voters know that they have to discount campaign promises to some extent as "cheap talk" since candidates have been known to promise "the moon" for a few extra votes.

With the in-party and out-party candidates taking essentially counterbalancing strategies to the campaign, many of their effects may be offset by one another, leading to a more closely decided election than otherwise would be the case (Campbell, 2008a). As much as popular incumbents, for instance, would like their campaigns to be purely about their wonderful records and about how important they were to those achievements, their opponents and, to some extent, the media and the voters will not let them dominate the election. Similarly, as much as successor candidates of parties with unpopular incumbents would like to make the election about anything else, their opponents, the media, and the public may have other ideas. Who gets their way depends on the predispositions of the electorate, the merits of the cases for the candidates, and the abilities of the candidates to make those cases to the right voters at the right time. But in the end, in a competitive election, no candidate's campaign message goes unchallenged.

The effects of the in-party's campaign (as well as to the out-party's campaign) are also limited by the preferences and activities of the voters and the media. Elections are not simply decided by what the candidates' strategies present to voters. Those in the media have their own agenda and voters have theirs. All of the campaigns' messages are judged by voters who have their own predispositions about the parties and candidates. The relative abilities of candidates and their campaigns to execute their strategies effectively and various aspects of the political record and policy proposals (the merits of their cases) also are critically important to the election's outcome. This is to say that, while the context is important to campaign strategy, strategy may prove stronger or weaker under varying conditions and campaign strategy is normally not determinative of the election's outcome. Candidates can play their cards exceedingly well, but it is hard to win if you are dealt a bad hand. 
With the above caveats in mind, the theory of the contextual campaign suggests several general tendencies for campaigns (assuming that candidates adopt their prescribed strategies in Tables 1 and 2). While there is much that goes on in elections that is well beyond the control of the candidates' campaigns, and while the symmetry of campaign strategies (and resources) suggests minimal and competitive effects, there are some important asymmetries to bear in mind. First, whether popular or not, the incumbent is given something close to full credit or full blame for the state of the nation (the record) under his or her watch. Unpopular incumbents can make excuses and the opponents of popular incumbents can try to diminish accomplishments, but the record is the record and voters know where "the buck stops." Presidents are held accountable for developments on their watches. Voters apply the retrospective voting rule with full force when the incumbent is on the ballot.

The context of incumbency may change the intensity in which voters apply the retrospective voting rule. Accountability for the record is less of a factor in open seat contests. For better or worse, successor candidates are not the incumbent and the political climate left by the incumbent will not affect them as much as it would the incumbent. However, this does not mean that successor candidates are completely immune to the effects of the prior record. Often, the successor candidate was an important member of the prior administration, most commonly serving as the vice-president. At minimum, the successor candidate shares a party affiliation with the incumbent administration. Successor candidates can try as they might to associate or to dissociate themselves from the incumbents' records, depending on whether the record is popular, but they are limited in their ability to do so. Successors are to various degrees and by several means attached to the prior administration, through party affiliation, official positions in the administration, or previous statements of support. These serve to retain a connection between the successor candidate and the record, though to a reduced degree than if the actual incumbent were running for reelection. With the record most clearly tied to the incumbent, voters should have more definite impressions of incumbents and should experience greater uncertainty in open seat races in which the amount of credit or blame for national conditions that should properly be assigned to the successor candidate is more contestable.

The theory of contextual campaigns and the idea that retrospective voting is conditional-stronger when an incumbent is in the race and weaker when the in-party candidate is not the incumbent-is a marked departure from the general assumptions of retrospective voting research.

While some have suggested that the judgments based on the economic record have conditional effects on the vote (Hibbing and Alford, 1981; Nadeau and Lewis-Beck, 2001; Campbell, 2001a; Norpoth, 2002) and others that general approval evaluations of the incumbent's record have a similar conditional impact (Campbell, 2001a; Holbrook, 2008), most studies of 
retrospective evaluations assume a general or unconditional retrospective evaluation effect (Fiorina, 1981; Kiewiet and Rivers, 1984; Fiorina, Abrams, and Pope, 2003; Abramowitz, 2008; Erikson and Wlezien, 2008; Sidman, Mak, and Lebo, 2008).

\section{THE HYPOTHESES AND THE DATA}

The theory of contextual campaigns would ideally be tested directly with evaluations of how closely presidential campaigns followed the prescribed strategy and how they fared compared to what they otherwise might have expected. In other words, whether they did as well as they possibly could under the circumstances. However, since we lack data regarding the campaigns directly, we offer several hypotheses and tests that examine the theory indirectly through its suspected implications on the electorate's evaluations and votes.

The implications of the theory of contextual campaigns lead to several expectations about voting behavior in the different contexts. First, because incumbents are more closely associated with national conditions than are successor candidates, the national conditions as reflected in presidential approval rates should be more closely associated with the vote for incumbents than for successor candidates. Second, because of the greater uncertainty in evaluations of successor candidates, given their lesser and variable association with their predecessor's record, evaluations and the vote for successor candidates should generally be more neutral than they are for incumbents and should generally be less closely associated with evaluations of national conditions.

Figure 1 displays the hypothesized difference between the relationship of political climate and the vote for incumbents and for successor candidates. Support at both ends of the political climate distributions level off as candidates receive diminishing returns in either party's base. The political climate simply does not matter much to a party's base that believes that things could only get worse if the opposing party were in power. The most important aspect of Figure 1 is the greater range and steeper slope for incumbents than for successors. Because of a more definite tie to the political climate and because the political climate itself is more uniformly judged as good (or bad) since conditions are directly experienced by the voters and are less easily rationalized in favor of a party, incumbents should experience higher highs and lower lows. In contrast, the greater uncertainty about successor candidates should produce less definite and more neutral impressions. Successor candidates should have lower highs and higher lows. In terms of the vote, campaigns with successor candidates should be expected to produce generally closer election results.

There are two pairs of hypotheses regarding the electoral effects of the theory of contextual campaigns. The first pair of hypotheses concerns the differences between elections in which an incumbent is in the race and those open seat races with a successor in-party candidate. The second pair of 


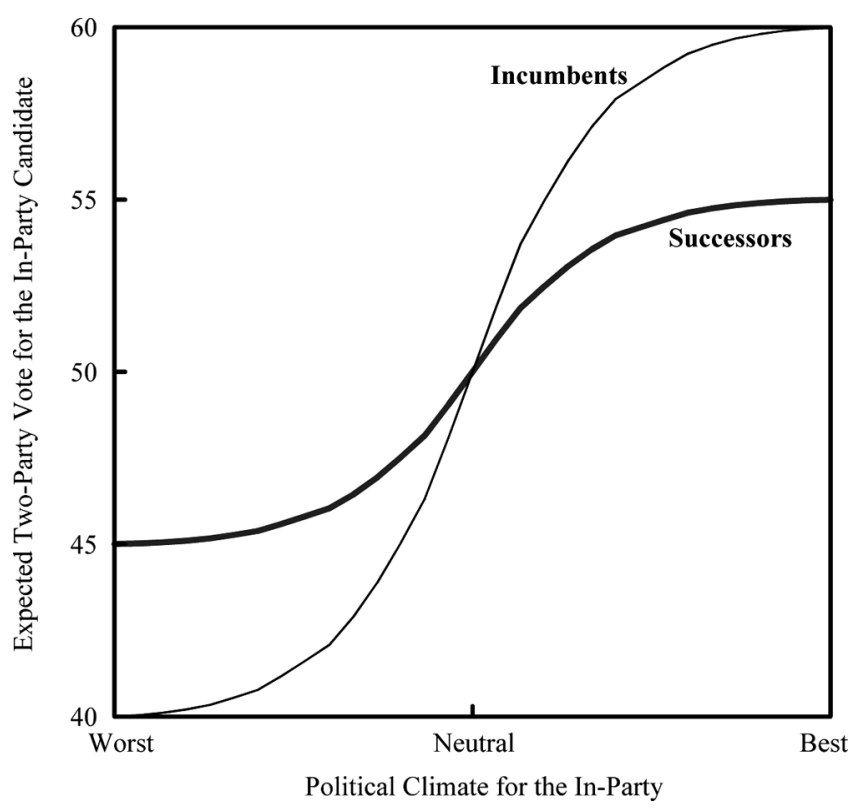

FIGURE 1 Hypothesized presidential vote for in-party candidates under the range of incumbency and political climate conditions.

hypotheses concerns the difference between voter evaluations of the incumbent and the successor candidate in open seat elections.

The hypotheses are as follows:

1. The effect of presidential approval on support for the in-party candidate is likely to be stronger in elections in which the incumbent is a presidential candidate than in elections in which the in-party candidate is not the incumbent.

2. The variance in the vote shares for in-party candidates who are incumbents is likely to be greater than the variance in the vote shares for in-party candidates who are not the incumbent.

3. In open seat presidential elections, affect for the successor candidate of the in-party is likely to be more neutral than affect for the incumbent.

4. In open seat presidential elections, the effect of affect for successor candidates on the vote choice is likely to be stronger than is the effect of affect for the incumbent.

The testing of these four hypotheses requires four variables measured at the individual level or aggregated for the electorate. The required variables are presidential approval ratings (hypothesis 1 ), individual-level thermometer scores for the incumbent and their successor candidates (hypotheses 3 and 4), 280 and aggregate and individual-level measures of the presidential vote 
(hypotheses 2 and 4). Individual-level data regarding approval ratings, thermometer scores, and reported individual votes are collected in the National Election Study (NES) surveys. The thermometer and approval ratings are from the pre-election wave of the NES. The thermometer ratings are available in NES surveys beginning with the 1968 election, and the presidential approval data are available beginning with the 1972 election. This permits analysis of approval ratings in three open seat elections (1988, 2000, and 2008) and analysis of thermometer ratings in a fourth open seat contest (1968). The analysis also includes the seven elections since 1968 in which the incumbent sought reelection. The aggregate national vote shares are calculated from CQ's Guide to U.S. Elections (Congressional Quarterly, 2005) and Dave Leip's Atlas of Presidential Elections (Leip, 2009) for the 2008 national vote.

\section{THE OPEN SEAT ELECTIONS}

The four open seat elections examined provide a good deal of variation to explore. The 1968 election was one of the most contentious in history. The candidates were in-party Democrat and sitting Vice-President Hubert Humphrey, Republican Richard Nixon, and third-party candidate George Wallace. The political climate was turbulent and mildly negative for the in-party. The country and especially the Democratic Party were deeply divided over the Vietnam War and civil rights. President Johnson's approval rating in late September of 1968, according to Gallup, was 42 percent. Historically, presidents have needed approval ratings above 45 percent to win the popular vote since a number of those who disapprove of the president disapprove of the opposing party's candidate even more strongly. Nevertheless, though the political climate was more divided than negative for the in-party, it was negative enough that President Johnson decided not to run when he could have. Unlike the other open seat contests that we can examine, this was not an open seat because of the two-term presidential limit imposed by the 22nd amendment. With this background, Humphrey had good reason to put some distance between himself and Johnson, though as vice-president he did so reluctantly and with limited success. He was stuck between a rock and a hard place. He needed the support of Johnson loyalists, but at the same time needed the support of the anti-Vietnam war wing of the party. He could not appeal to one without offending the other and, as Johnson's vice-president, he would never have

Q1 been fully trusted by the antiwar wing of the party. Humphrey eventually attempted to make the break with Johnson on Vietnam (Buell and Sigelman, 2008 , 98). He made a strong charge at the end of the campaign but lost to Nixon in a very close election.

The second open seat election examined is the 1988 election, which took place under very different circumstances, though again it involved a sitting 
vice-president attempting to succeed to the White House. Republican Vice-President George H. W. Bush sought to succeed President Reagan and was opposed by the Democrats' nominee, Governor Michael Dukakis of Massachusetts. The political climate was quite favorable to the in-party. Despite being bruised by the Iran-Contra controversy, President Reagan remained quite popular. His approval rating in late September 1988, according to Gallup, was 54 percent, well above the mid-40s threshold that seems to be what is needed for an incumbent to win reelection. George H. W. Bush quite clearly adopted the strategy recommended for a successor candidate running in a favorable political climate. The following excerpt from Bush's convention acceptance speech highlights for voters the close Reagan-Bush association:

For seven and a half years I have helped the president conduct the most difficult job on earth. Ronald Reagan asked for, and received, my candor. He never asked for, but he did receive, my loyalty.... Eight years ago, eight years ago, I stood here with Ronald Reagan and we promised, together, to break with the past and return America to her greatness. Eight years later, look at what the American people have produced: the highest level of economic growth in our entire history-and the lowest level of world tensions in more than fifty years (Bush, 1988).

As the sitting vice-president, Bush had a particularly easy case to make with voters that a vote for him was as close as they could come to voting for a third Reagan term (Mattei and Weisberg, 1994). The strategy appeared to work, as Bush defeated his Democratic rival by a margin of about 54 to 46 in the national popular two-party vote.

The third open seat election examined is the contested election of 2000 between in-party Democratic Vice-President Al Gore and Republican George W. Bush. Despite multiple scandals and the impeachment of President Clinton, the economy appeared robust and the approval ratings for the president's job performance remained strong. The average of 12 polls in September 2000 indicated a 58 percent job approval rating for President Clinton (Roper Center, 2009). While the theory contends that Gore should have run a retrospective campaign emphasizing a close association between Clinton and Gore, the Gore campaign decided instead to adopt a prospective strategy, making minimal use of and association with President Clinton (Campbell, 2001a). Nowhere was this choice of strategy more starkly stated than in Gore's nomination acceptance speech at the Democratic national convention. After briefly mentioning what he regarded as the successes of the Clinton administration, he then told the delegates and the nation:

This election is not an award for past performance. I'm not asking you to vote for me on the basis of the economy we have. Tonight I ask for your support on the basis of the better, fairer, more prosperous America we can build together (Gore, 2000). 
This was the kickoff of Gore's prospectively oriented class politics campaign that oddly avoided mentioning the candidate's association with President Clinton, much less emphasizing it. The departure of Gore's strategy from that recommended by the theory actually suggests the wisdom of the theory. While the fundamentals suggested a strong Democratic year in 2000 and while Gore won a majority of the popular vote, that majority was far less than might have been expected and was so close that his opponent won the electoral vote majority. Though voters do not depend on the candidates to make associations with the records and thought Gore would not have received the same credit for conditions that Clinton would have

Q2 received had he been able to run. Gore's decision not to make a strong effort to claim as much credit for what most voters regarded as good national conditions may well have cost him the White House (Campbell, 2001a, 2001b; Lewis-Beck and Tien, 2004).

The fourth open seat election examined is the 2008 election between in-party Republican John McCain and Democrat Barack Obama. Of the four open seat elections examined, the 2008 election clearly had the worst political climate for the in-party but also had the successor candidate best positioned to distance himself from the previous administration. The poor political climate was encapsulated in President Bush's anemic approval ratings. The president's ratings, according to Gallup, had been below 40\% since October 2006 and remained below 35\% throughout $2008 .{ }^{1}$ In the five Gallup polls conducted in the 10 weeks prior to the conventions, his rating averaged a mere 31 percent, well below the mid-40s threshold of a politically neutral climate.

Though the political climate was particularly bad for the Republicans in 2008, their candidate was also unusually well positioned to distance himself from that record. Senator McCain was not only not a sitting vice-president, as so many successor candidates have been, but he had been the major rival to President Bush for the party's nomination in 2000, had an established reputation and voting record of being a moderate in the Senate, and had even been courted as a possible running mate for John Kerry on the 2004 Democratic ticket. In short, the context of the 2008 election was one in which the in-party candidate had strong reasons to distance himself from the incumbent's record and, more than any successor candidate in modern history, had the background that provided him with the credibility to do just that.

The review of the open seat elections since 1968 indicate that, though few in number, there is a good deal of variance among them. The political climates ranged from strongly favorable (2000) or somewhat favorable (1988) to the in-party to strongly unfavorable (2008) or somewhat unfavorable (1968) to it. While three of these elections involved sitting vicepresidents who are naturally more closely associated with their incumbent's record (Mattei and Weisberg, 1994), the 2008 election involved a successor candidate in John McCain who could quite plausibly set himself apart from the prior administration and had good reason to do so. 
We now turn to the analysis of the four hypotheses of the contextual campaigns theory involving how incumbent elections and open seat elections differ and how evaluations of incumbents and successor candidates differ in open seat contests.

\section{FINDINGS}

\section{Incumbents and Open Seat Elections}

The first hypothesis is that the political climate for the in-party as measured by presidential approval ratings tends be more strongly related to support for the in-party candidate in elections in which the incumbent is running as opposed to successor in-party candidates in open seat elections. Two measures of support for the in-party candidate are employed in testing the hypothesis: the in-party candidate's thermometer rating and the reported vote for the in-party candidate.

Table 3 reports the estimated effects of presidential approval on in-party candidate thermometer ratings and the reported vote in both incumbent elections and open seat elections since 1972. The effects of approval on in-party thermometer ratings are ordinary least squares regression estimates. The

TABLE 3 Relation of Presidential Approval and In-Party Candidate Support, 1972-2008

\begin{tabular}{|c|c|c|c|c|}
\hline \multirow{3}{*}{$\begin{array}{l}\text { Association between presiden- } \\
\text { tial approval and support for } \\
\text { the in-party candidate } \\
\text { Type of in-party candidate }\end{array}$} & \multicolumn{4}{|c|}{ Coefficients of effect of presidential approval on } \\
\hline & \multicolumn{2}{|c|}{$\begin{array}{l}\text { In-party candidate } \\
\text { thermometer rating }\end{array}$} & \multicolumn{2}{|c|}{$\begin{array}{l}\text { In-party candidate } \\
\text { presidential vote }\end{array}$} \\
\hline & $\mathrm{b}$ & $\mathrm{r}$ & $\mathrm{b}$ & Somer's d \\
\hline \multicolumn{5}{|l|}{ Incumbent in the race } \\
\hline 1972 & 42.07 & .69 & 3.40 & .60 \\
\hline 1976 & 30.67 & .64 & 3.39 & .60 \\
\hline 1980 & 36.86 & .64 & 2.95 & .61 \\
\hline 1984 & 48.58 & .79 & 4.47 & .74 \\
\hline 1992 & 37.89 & .68 & 3.55 & .71 \\
\hline 1996 & 51.51 & .81 & 4.74 & .73 \\
\hline 2004 & 58.65 & .85 & 4.88 & .84 \\
\hline Mean for incumbent races & 43.75 & .73 & 3.91 & .69 \\
\hline \multicolumn{5}{|l|}{ Successor candidate (open seat) } \\
\hline 1988 & 37.95 & .65 & 3.35 & .64 \\
\hline 2000 & 33.85 & .62 & 3.00 & .57 \\
\hline 2008 & 22.48 & .43 & 3.06 & .51 \\
\hline Mean for successor races & 31.43 & .57 & 3.14 & .57 \\
\hline
\end{tabular}

All of the b coefficients of approval effects are statistically significant at $p<.01$, one-tailed. The effects of approval on thermometer ratings are ordinary least squares estimates. The effects of approval on the vote are logit estimates. Somer's d is a nonparametric measure of association appropriate for noncontinuous data. The data are from the NES surveys. The thermometer rating are from the pre-election wave of the NES. 
effects of approval on the reported vote are logit estimates. Whether support is measured by thermometer evaluation ratings or the vote, presidential approval ratings affect support for all in-party candidates but have a greater impact on and are more strongly correlated with support for incumbents than for successor candidates. Based on the mean estimates, there is typically a 44-thermometer degree difference in the rating of an incumbent between those who approve of the incumbent's job performance and those who disapprove. When the in-party candidate is not the incumbent, the difference between those approving and those disapproving of the incumbent's job performance is significantly smaller, only about 31 thermometer degrees. The impact of presidential approval on the in-party vote in open seat races is similarly smaller and less closely related than it is in incumbent races. In short, for better or worse, incumbents "own" their records. Successor candidates, on the other hand, are more or less associated with the record by virtue of their common partisanship and personal histories (roles in the administration and personal records of supporting the administration). The observed differences support the first hypothesis.

One aspect of Table 3 is especially noteworthy. The impact of President Bush's approval rating in 2008 on the pre-election thermometer ratings of John McCain was particularly weak. The slope coefficient was only about 22 thermometer degrees and the correlation of presidential approval and successor thermometer ratings in 2008 was only 0.43 . These associations are substantially smaller than any others in the series. Compared to any of the other successor candidates, McCain's thermometer ratings and his vote depended less on how voters regarded his party's incumbent. Even so, it is also interesting that the effect of presidential approval on the vote in 2008, though weaker than in any other election in the series (according to the Somer's d correlation), was not as distinctively weak as it was in its impact on the pre-election thermometer rating. This appears to support the view that the Wall Street meltdown in mid-September was a pivotal event that significantly worsened the political climate for the in-party in the election and refocused voter attention on the weaknesses of in-party's record (Campbell, 2008b).

The second hypothesis suggests that because of the greater variability in the association of successor candidates with the record of the outgoing administration, evaluations of successor candidates should be more tepid. Lacking the clear experience that voters have had with incumbents, they should be less certain about and more moderate about whether they favor or oppose successor candidates. The electoral verdict regarding races with successor candidates rather than incumbents should be more modulated. This should be evident in the variance in the vote for successor candidates and incumbents. More voters should be sure whether they like or dislike an incumbent's performance than whether they like or dislike the prospective performance of a relatively lesser known successor candidate. The 
variance of the vote in incumbent races should be greater than the variance of the vote in successor races. This is exactly what we find in Table 4.

Table 4 presents the standard deviations of the two-party popular vote for in-party candidates in incumbent races and open seat races for the 16 presidential elections since World War II and also for the 36 presidential elections since the Civil War. In both cases, the variance of the vote is greater in incumbent races compared to open seat contests. For the most recent series, the standard deviation of the in-party vote is nearly twice as large for incumbent contests as open seat elections (6.09 versus 3.37). Though to a somewhat smaller extent, the same difference is found for elections conducted since 1868. As expected by the hypothesis and as portrayed in Figure 1, open seat elections in which the in-party candidate is less clearly responsible for national conditions tend to be closer elections. In presidential elections since 1868,40 percent of open seat elections ( 6 of 15 ) have been near-dead heat elections, while only 14 percent of incumbent elections ( 3 of 21) have been this close (Campbell, 2008a, 109). ${ }^{2}$ When the incumbent is on the ballot, voters use their more definite and more uniform evaluations of the record to render a more decisive verdict.

\section{Incumbents and Successors in Open Seat Elections}

The third and fourth hypotheses shift the focus from the difference between incumbent and open seat elections to the difference between how voters evaluate incumbents and successor candidates in open seat elections. The third hypothesis is that evaluations of successor candidates in open seat elections are more neutral than their evaluations of incumbents. The test of this hypothesis is the determination of whether those who rate incumbents highly rate successor candidates less so and whether those who rate incumbents poorly also rate successor candidates less so. Table 5 presents a set of regressions in open seat elections with the thermometer for the successor candidate as the dependent variable and the thermometer for the incumbent as the independent variable. The regressions were estimated both for the entire NES sample and those reporting having voted for a major party candidate. The theoretical expectation is that the relationship between the

TABLE 4 Variance of the In-Party Vote Percentage With Incumbent and Successor Candidates, 1868-2008

\begin{tabular}{lcc}
\hline & \multicolumn{2}{c}{ Standard deviation of the in-party vote } \\
\cline { 2 - 3 } Elections & Incumbents in the race & Successor candidates (Open seats) \\
\hline $1948-2008$ & $6.09(\mathrm{~N}=10)$ & $3.37(\mathrm{~N}=6)$ \\
$1868-2008$ & $7.30(\mathrm{~N}=22)$ & $5.25(\mathrm{~N}=14)$ \\
\hline
\end{tabular}

The vote percentage is of the two-party national popular vote. 
TABLE 5 Impact of Affect for Incumbents on Affect for In-Party Successor Candidates in Open Seat Elections, 1968-2008

\begin{tabular}{lcccc}
\hline \multicolumn{4}{l}{ Dependent variable: Successor candidate thermometer rating } \\
\hline Independent variables & 1968 & 1988 & 2000 & 2008 \\
\hline All respondents & & & & \\
Incumbent & .72 & .67 & .62 & .56 \\
Thermometer & $(.02)$ & $(.01)$ & $(.01)$ & $(.02)$ \\
Constant & 19.77 & 19.41 & 23.05 & 29.72 \\
& $(1.29)$ & $(.91)$ & $(.89)$ & $(.69)$ \\
$\mathrm{N}$ & 1,305 & 1,967 & 1,771 & 2,080 \\
Adjusted $\mathrm{R}^{2}$ & .49 & .56 & .52 & .41 \\
Reported Voters & & & & .64 \\
Incumbent & .73 & .74 & $(.02)$ & $. .02)$ \\
Thermometer & $. .02)$ & $(.02)$ & 23.33 & 30.35 \\
Constant & 20.68 & 15.79 & $(1.06)$ & $(.78)$ \\
& $(1.55)$ & $(1.11)$ & 1,111 & 1,530 \\
$\mathrm{~N}$ & 868 & 1,179 & .55 & .43 \\
Adjusted $\mathrm{R}^{2}$ & .52 & .64 & & \\
\hline
\end{tabular}

All of the coefficients are statistically significant at $p<.01$, one-tailed. Standard errors are in parentheses. For $\mathrm{b}$, the null hypothesis is that $\mathrm{b}=1$. The theoretical expectation or alternative hypothesis is that $\mathrm{b}<1$. The thermometer ratings are from the pre-election wave of the NES.

incumbent's rating and the successor candidate's rating should have a slope that is significantly less than one.

The findings in Table 5 support the contention of the third hypothesis. In each of the open seat elections, the relationship between the thermometer rating for the incumbent and that for the successor was significantly flatter than a slope of one, whether examining that relationship among all respondents or among reported voters. In each regression, affect for the incumbent is positively related to affect for the successor candidate but is related on significantly less than a one-to-one basis. The incumbent thermometer coefficients indicate that for every 10 thermometer degrees a person rates the incumbent, he or she is likely to rate the successor candidate between about 6 or 7 thermometer degrees higher.

Again, as in the case of presidential approval effects on the thermometer ratings and vote for successor candidates, the 2008 election stands out as one in which the effects are especially weak. How warmly people felt toward President Bush affected how warmly they felt toward McCain, but the relationship with the incumbent's rating was weaker than it had been for the any of the three other successor candidates who were examined.

The fourth hypothesis is that the in-party vote in open seat elections depends more on what voters think about the successor candidate than what they think about the incumbent. If so, this suggests that the distance between evaluations of successor candidates and incumbents, whether successor candidates try to be closely tied to popular incumbents or dissociated from 
unpopular incumbents, matters to the vote. The hypothesis is tested with logit analyses of the effects of the incumbent's and the successor candidate's thermometer rating in the four open seat elections. The theoretical expectation is that the thermometer ratings for the successor candidates matter more to the vote than the ratings for the incumbents. Table 6 displays the logit results. Since logit coefficients are difficult to interpret intuitively, we have computed the difference in the expected in-party vote for voters who rated the incumbent or successor at 75 degrees and the expected in-party vote for those who expressed ratings of 25 degrees.

In each open seat election examined, as the hypothesis contends, evaluations of the successor candidate actually running for the presidency matter more to the vote than do evaluations of the incumbent. In every open seat election examined, with the exception of 1968, the incumbent's rating mattered as well as the actual successor candidate's rating, but in each case the successor candidate's rating made a much greater difference to the vote. Of course, as suggested by the findings in Tables 3 and 5, evaluations of successor candidates are strongly influenced by the political climate and evaluations of the incumbent; even so, in the end, the vote choice in open seat contests is substantially influenced by evaluations of the successor candidates and those entail more, sometimes much more, than a transfer of support or opposition from the incumbent. As the hypothesis contends, open seat elections are not simply referenda on the incumbent's record or even the incumbent more generally. How voters regard the successor candidate and the candidate's positions and background, as well as how closely

TABLE 6 Impact of Affect for Incumbents and Successors on the In-Party Vote in Open Seat Elections, 1968-2008

\begin{tabular}{|c|c|c|c|c|}
\hline \multicolumn{5}{|l|}{ Dependent variable: Vote for in-party candidate } \\
\hline Independent variables & 1968 & 1988 & 2000 & 2008 \\
\hline Incumbent thermometer & $\begin{array}{l}0.000 \\
(.006)\end{array}$ & $\begin{array}{c}0.045^{*} \\
(.005)\end{array}$ & $\begin{array}{c}0.043^{*} \\
(.004)\end{array}$ & $\begin{array}{l}0.043^{*} \\
(.004)\end{array}$ \\
\hline Successor thermometer & $\begin{array}{l}0.127^{*} \\
(.010)\end{array}$ & $\begin{array}{l}0.055^{*} \\
(.007)\end{array}$ & $\begin{array}{r}0.064^{*} \\
(.007)\end{array}$ & $\begin{array}{l}0.068^{*} \\
(.008)\end{array}$ \\
\hline Constant & $\begin{array}{r}-8.88^{*} \\
(.639)\end{array}$ & $\begin{array}{r}-6.25^{*} \\
(.397)\end{array}$ & $\begin{aligned}-5.98^{*} \\
(.423)\end{aligned}$ & $\begin{aligned}-5.95^{*} \\
(.488)\end{aligned}$ \\
\hline $\begin{array}{l}\text { Expected vote \% difference between ratings } \\
25 \text { and } 75 \text { for incumbent thermometer }\end{array}$ & 0.2 & 47.3 & 48.2 & 30.20 \\
\hline $\begin{array}{l}\text { Expected vote } \% \text { difference between ratings } \\
25 \text { and } 75 \text { for successor thermometer }\end{array}$ & 65.9 & 54.1 & 63.9 & 56.72 \\
\hline$\%$ predicted correctly & 86.4 & 84.1 & 86.1 & 86.4 \\
\hline$\%$ reduction in error & 70.9 & 66.0 & 70.9 & 59.4 \\
\hline $\mathrm{N}$ & 868 & 1,179 & 1,111 & 1,526 \\
\hline
\end{tabular}


the successor candidate is associated with the prior administration, is what is critical to the vote.

\section{DISCUSSION}

This analysis of the four hypotheses of the theory of contextual campaigns has produced a consistent array of evidence in support of the theory. Incumbents own their records, but successor candidates do not. Presidential elections with incumbents are substantially, though not entirely, referendums on the performance of the incumbent. The incumbent's record matters in an open seat election, but not quite as much.

The difference between a race with a presidential incumbent and one with an in-party successor candidate is in some respects like the difference between presidential and midterm elections. In the presidential election, the presidential candidates are clearly the focal point of the decision. In the midterm election, the record of the president matters a good deal, but it is not the same as his or her being literally on the ballot. So it is with incumbent presidential elections and open seat presidential elections. When the incumbent is running, he or she is the focal point. In open seats, the incumbent and his or her record matters, but not to the same degree.

Open seat presidential elections entail greater uncertainty about the choices. Neither candidate is a candidate known to the same degree, but the record of the in-party is still important information for voters. The contextual campaigns theory contends that successor candidates with popular incumbents should attempt to run as their heir apparents, especially if the case is as strong as it is for sitting vice-presidents. This strategy helped to elect President George H. W. Bush in 1988.

The wisdom of the strategy is demonstrated by the negative outcome of violating it in the 2000 election. Though many voters who thought well of the Clinton administration's record did not need to be reminded by the Gore campaign of the candidate's association, the decision by the Gore campaign not to make "a third Clinton term" the core of its campaign message may have cost Gore the election. Note from Tables 3 and 5 that Gore inherited proportionately less support from Clinton than George H. W. Bush inherited from Reagan.

Successor candidates with unpopular incumbents, according to the theory, should do what they can to distinguish themselves from their incumbents. As President Johnson's vice-president, Hubert Humphrey in 1968 was quite constrained in how effectively he could distinguish himself from Johnson. This was not the case for John McCain in 2008.

\section{The 2008 Presidential Election}

Unlike other successor candidates in recent decades, John McCain had both the opportunity and motivation to set himself apart from the incumbent. 
McCain's background provided him with an unusual opportunity to put distance between himself and President Bush in the minds of voters. Since he was not a sitting vice-president, had in fact been a rival to the incumbent, and had been courted by Democrats 4 years earlier to run on their ticket, there was a strong prima facie case that McCain was not a George W. Bush clone. Added to this was McCain's very moderate voting record in the Senate and his conspicuous bipartisanship on matters from campaign finance reform to opposition to streamlining judicial appointment considerations ("the nuclear option") in the Senate. McCain's moderate conservative and bipartisan credentials were so much in evidence that it seemed at times that he was having more of a problem convincing conservatives that he was one of them than convincing moderates that he was not George Bush. Obama tried to make the case that McCain was Bush, but it was a hard case to make and seemed to fall flat except among die-hard Democrats.

McCain also had an unusually strong incentive to distance himself from President Bush. Of course, the president's anemic approval ratings in themselves provided a strong motive to keep the president at arm's length. If McCain and Bush were indistinguishable to voters, the election would be lost. But beyond this, the fact that Bush had lost a good deal of support even within his own party was in a way liberating for McCain as a candidate. While being respectful of the incumbent, he could criticize the administration and his own party without much fear of a party backlash from Bush loyalists. Since he was not Bush's vice-president, he did not face the dilemma that many other successor candidates face of trying to demonstrate independence from the incumbent without appearing disloyal. McCain's only hope of winning was in establishing his own independent political identity as virtually a nonpartisan candidate well removed from the incumbent administration, and given the candidate's unusual background, the chances of it working were reasonably good. That was the course set to win back the voters who 4 years earlier carried Bush to victory but were now disgruntled.

McCain's job of winning back a significant number of voters who disapproved of President Bush was made easier by the partisanship and polarization of the electorate. Most of the loss in President Bush's support between his reelection in 2004 and the outset of the 2008 campaign came from disenchanted Republicans. President Bush's popularity dropped 17 points from an approval rating of 48 percent at his reelection in 2004 to only 31 percent in July of 2008. Virtually none of this loss was among Democrats. They did not care for him in 2004 and this had hardly changed at all by the summer of 2008. From November 2004 to July 2008, approval of President Bush among Democrats declined from 11 percent to 7 percent. Among Republicans, on the other hand, his approval over this period dropped from a sky-high 93 percent to 67 percent. The third of Republican who disapproved of Bush in 2008 were unlikely Obama voters and were good targets to be won over by McCain. Indeed, post-election NES data indicate that among voting 
Republican partisans who disapproved of President Bush's job performance, 80 percent voted set their disapproval of Bush aside and voted for McCain.

McCain's success in running a campaign somewhat independent of the Bush presidency is evident in the association of the president's approval ratings in the midsummer of the election year and the in-party candidate's poll standing in the early fall. Presidential approval ratings in July of an election year have historically been closely associated with in-party candidate's preference poll standing in early September $(r=.82$ in elections from 1948 to 2004). All nine in-party candidates whose incumbent had an approval rating of more than 45 percent in July's Gallup poll have led in the early September preference polls. Of the seven in-party candidates with incumbents having approval ratings of 45 percent or less in July, six trailed in the early September preference poll. The single exception to this 60-year consistency was 2008. Despite Bush having a July approval rating below 45 percent, McCain actually led in the early September polls, with 52.7 percent of the two-party split (Campbell, 2008b). In fact, McCain led in the early September polls despite the fact that President Bush was not just below the mid-40 s threshold: his approval rating stood at only 31 percent in July. This was tied for the lowest July approval of any president since 1948, yet McCain as the in-party candidate actually led in the post-convention polls.

Despite a president with anemic approval ratings for the whole election year, John McCain was able to run very close to Barack Obama in the run-up to the national conventions and then take the lead after the conventions. Gallup's mean August pre-convention polls of registered voters (August 1 through August 24) had the race at 51.3 percent Obama to 48.7 percent McCain. The RealClearPolitics average of polls over the same period had the race at 51.7 percent Obama to 48.3 percent McCain. ${ }^{3}$ A swing of less than two points separated the candidates. If you also consider the higher propensity of registered Republicans to turn out to vote, then the race was a toss-up going into the conventions. ${ }^{4}$ Moreover, both Gallup and the RealClearPolitics average of polls had McCain closing in on Obama in the days before the Democratic convention. Over the 10 days leading up to the convention, Gallup's polls averaged 50.6 percent for Obama to 49.4 percent for McCain, and the final two pre-convention Gallup polls had the race tied. McCain actually emerged from the convention period with a small lead, according to the Gallup and RealClearPolitics readings. Immediately after the Republican convention, McCain held a 52.7 percent share of support in Gallup's poll and 50.5 percent in the RealClearPolitics average of polls.

McCain held a poll lead over Obama in both until the middle of September when Wall Street went into meltdown. The collapse of the financial markets caused both President Bush's approval ratings to sink even lower (dropping 6 points, from 31 to 25 percent), and McCain's numbers followed. In a little more than 3 weeks, from September 14 (allowing some time for the convention bump to recede) to October 6, John McCain's share 
in Gallup's tracking poll dropped 6 points, from 51 to 45 percent. The unanticipated financial crisis that many analysts and voters termed as the greatest economic crisis since the Great Depression was a political "game changer" that derailed what had been shaping up to be a very close election despite the poor political climate for the in-party (Campbell, 2008b).

Taking the Wall Street meltdown effects into account, the 2008 election offers strong evidence on behalf of the theory of contextual campaigns. In late July 2008, Alan Abramowitz, Mann, and Sabato (2008) took stock of the political climate for the 2008 election and concluded that "It is no exaggeration to say that the political environment this year is one of the worst for a party in the White House in the past sixty years." Yet despite this-the unpopular war in Iraq, a sluggish economy, and a highly unpopular president-McCain and Obama were in a tight race up to the conventions, and McCain held a post-convention poll lead over his rival up to the point of the meltdown. Even with a hostile political climate plus the unprecedented financial crisis striking in the middle of the campaign, McCain wound up with 46.3 percent of the two-party vote to Obama's 53.7 percent. By historical standards, this was a solid but unremarkable plurality for Obama under quite remarkable political and economic conditions.

\section{Referendums in Context}

In his analysis of the 2008 election, Gary Jacobson states that "a modern presidential election is always largely a referendum on the performance of the current administration" (2009, 3). The key words here are "always" and "largely." It is clear from our analysis that while the performance of the current administration always has an effect on presidential elections, this effect is not the same in incumbent and open seat contests and the extent of the effect varies considerably according to the background of the successor candidate and the political climate in open seat races. With the pre-campaign

political climate as terrible as it was for Republicans in 2008, as Abramowitz et al. (2008) correctly described, the simple referendum theory of presidential elections would have led us to expect that (1) McCain never would have been close to Obama in any meaningful poll (e.g., the polls immediately preceding the conventions), (2) McCain never would have a post-convention poll lead over Obama for any significant length of time, and (3) Obama would have won the election in a landslide. Each of these expectations were wrong: McCain and Obama were in a pitched battle before the conventions, McCain emerged from them with a lead until mid-September, and Obama's victory was of about average size (Campbell, 2008b). Even adding the Wall Street meltdown to the out-party's side of the ledger could not drive the Obama vote beyond an average winning margin.

Retrospective voting does not entirely dominate elections, and it certainly does not always dominate presidential elections. This is particularly 
true of elections in which the incumbent is not running, and as 2008 proved, it is especially true of open seat elections in which a successor candidate can and does plausibly distance himself or herself from an unpopular incumbent. Voters are not so partisan that they cannot distinguish one candidate from another or one candidate from the incumbent. Contrary to the simple referendum theory of elections, presidential elections are not immutable or inevitable referendums on the current administration. Successor candidates need to devise plausible campaign strategies and messages that disassociate them from unpopular incumbents when possible and that align them more closely to popular incumbents when possible. Candidates who recognize this in devising their strategies can benefit from this understanding. Candidates who do not recognize this run the risk of making environmental movies rather than Supreme Court appointments.

\section{NOTES}

1. The presidential approval for 2008 used throughout are from Gallup at http://www.gallup.com/ Q5 poll/1723/Presidential-Job-Approval-Depth.aspx

2. Near-dead heat elections are defined as those in which the winning candidate received 51.5 percent or less of the two-party popular vote.

3. Throughout the campaign, the Gallup data were obtained at http://www.gallup.com/Home.aspx and the RealClearPolitics averages of the polls were collected from http://www.realclearpolitics.com/ polls/

4. The higher turnout rate of registered Republicans compared to registered Democrats is evident in NES data for every election in which they have conducted a study. According to NES data, Republicans again had a turnout advantage over Democrats in 2008. In the NES survey, 86 percent of Republicans reported that they voted compared to 78 percent of Democrats. An examination of the Democratic vote and the Democrat's standing in the early September Gallup Poll of registered voters in elections from 1948 to 2004 indicates that a Democrat candidate needs to be at 51.5 percent in the polls to expect 50 percent of the vote.

\section{REFERENCES}

Abramowitz, Alan I. (1991). Incumbency, campaign spending, and the decline of competition in House elections. The Journal of Politics, 53, 34-56.

- (2008). Forecasting the 2008 presidential election with the time-for-a-change model. PS: Political Science and Politics, 41, 691-695.

Abramowitz, Alan I., Thomas E. Mann, and Larry J. Sabato. (2008). The myth of a toss-up election. Larry J. Sabato's Crystal Ball., Retrieved July 24, 2008, from http://www.centerforpolitics.org/crystalball/

Alford, John R. and John R. Hibbing. (1981). Increased incumbency advantage in the House. Journal of Politics, 43, 1042-1061.

Buell, Emmett H., Jr. and Lee Sigelman. (2008). Attack politics: Negativity in presidential campaigns since 1960. Lawrence, KS: University Press of Kansas.

Bush, George H. W. (1988). 1988 Republican National Convention acceptance address. Retrieved _ from http://www.americanrhetoric.com/speeches/ georgehbush1988rnc.htm 
Campbell, Angus, Philip E. Converse, Warren E. Miller, and Donald E. Stokes. (1960). The American Voter. New York: Wiley.

Campbell, James E. (2008a). The American campaign, second edition: U.S. presidential campaigns and the national vote. College Station, TX: Texas A\&M 765 University Press.

- (2008b). An exceptional election: Performance, values, and crisis in the 2008 presidential election. The Forum: A Journal of Applied Research in Contemporary Politics, 6(4, article 7), 1-20.

- (2000). The American campaign: U.S. presidential campaigns and the national vote. College Station, TX: Texas A\&M University Press.

- (2001a). The referendum that didn't happen: The forecast of the 2000 presidential election. PS: Political Science and Politics, 34, 33-38.

- (2001b). The curious and close presidential campaign of 2000. In William Crotty (Ed.), America's choice 2000 (pp. 115-137). Boulder, CO: Westview.

Campbell, James E., Bryan J. Dettrey, and Hongxing Yin. (2009). The theory of conditional retrospective voting: Does the presidential record matter less in open seat elections? Manuscript.

Congressional Quarterly. (2005). CQ's guide to U.S. elections, 5th ed. Washington, DC: CQ Press.

Erikson, Robert S. and Christopher Wlezien. (2008). Leading economic indicators, the polls, and the presidential vote. PS: Political Science and Politics, 41, 703-707.

Fiorina, Morris P. (1981). Retrospective voting in American national elections. New Haven, CT: Yale University Press.

Fiorina, Morris, Samuel Abrams, and Jeremy Pope. (2003). The 2000 U.S. presidential election: Can retrospective voting be saved? British Journal of Political Science, 33, 163-187.

Gaddie, Ronald Keith and Charles S. Bullock, III. (2000). Elections to open seats in the U.S. House: Where the action is. Lanham, MD: Rowman and Littlefield.

Q6 Gallup Poll. (2008). Retrieved — from http://www.gallup.com/Home.aspx

Gore, Albert, Jr. (2000). Text: Gore's acceptance speech at the Democratic National Convention. The Washington Post. Retrieved August 17, 2008, from http:// washingtonpost.com/wp-srv/onpolitics/elections/goretext081700.htm

Hibbing, John R. and John R. Alford. (1981). The electoral impact of economic conditions: Who is held responsible? American Journal of Political Science, 25, 423-439.

Holbrook, Thomas M. (2008). Incumbency, national conditions, and the 2008 Presidential election. PS: Political Science and Politics, 41, 709-712.

Jacobson, Gary C. (2009). The 2008 presidential and congressional elections: Anti-Bush referendum and prospects for the Democratic majority. Political Science Quarterly, 124, 1-30.

Key, V. O. (1966). The responsible electorate. New York: Vintage Books.

Kiewiet, D. Roderick and Douglas Rivers. (1984). A retrospective on retrospective voting. Political Behavior, 6, 369-393.

Levitt, Steven and Catherine Wolfram. (1997). Decomposing the sources of incumbency advantage in the U.S. House. Legislative Studies Quarterly, 22, 45-60. 
Lewis-Beck, Michael S. and Charles Tien. (2004). Jobs and the job of president: A forecast for 2004. PS: Political Science and Politics, 37, 753-757.

Leip, Dave. (2009). Dave Leip's atlas of presidential elections. Retrieved — from http://uselectionatlas.org/

Lippman, Walter. (1925). The phantom public. New York: Harcourt Brace.

Mattei, Franco and Herbert F. Weisberg. (1994). Presidential succession effects in voting. British Journal of Political Science, 24, 495-516.

Mayhew, David R. (2008). Incumbency advantage in U.S. presidential elections: The historical record. Political Science Quarterly, 123, 201-228.

Miller, Arthur H. and Martin P. Wattenberg. (1985). Throwing the rascals out: Policy and performance evaluations of presidential candidates, 1952-1980. American Political Science Review, 79, 359-372.

Nadeau, Richard and Michael S. Lewis-Beck. (2001). National economic voting in U.S. presidential elections. Journal of Politics, 63, 159-181.

Norpoth, Helmut. (2002). On a short-leash: Term limits and the economic voter. In Han Dorussen and Michael Taylor (Eds.), Economic voting (pp. 121-136). Oxford: Routledge.

RealClearPolitics. (2008). General Election: McCain vs. Obama. Retrieved — from http://www.realclearpolitics.com/epolls/2008/president/us/general_election_

Q6 mccain_vs_obama-225html

Roper Center. (2009). Presidential approval. Retrieved — from http://www. ropercenter.uconn.edu/

Sidman, Andrew, Maxwell Mak, and Matthew J. Lebo. (2008). Forecasting non-incumbent presidential elections: Lessons learned from the 2000 election. International Journal of Forecasting, 24(2), 237-256.

Tenpas, Kathryn Dunn. (2003). Presidents as candidates: Inside the White House for the president's campaign. New York: Routledge.

Weisberg, Herbert F. (2002). Partisanship and incumbency in presidential elections. Political Behavior, 24(4), 339-360. 